\title{
Collingwood on religious atonement
}

\author{
Dale Jacquette
}

Received: 28 October 2013 / Accepted: 15 April 2014 / Published online: 29 April 2014

(C) Springer Science+Business Media Dordrecht 2014

\begin{abstract}
R. G. Collingwood's philosophical analysis of religious atonement as a dialectical process of mortal repentance and divine forgiveness is explained and criticized. Collingwood's Christian concept of atonement, in which Christ $=$ the Atonement (and also = the Incarnation), is subject in turn to another kind of dialectic, in which some of Collingwood's leading ideas are first surveyed, and then tested against objections in a philosophical evaluation of their virtues and defects, strengths and weaknesses. Collingwood's efforts to synthesize objective and subjective aspects of atonement, and his proposal to solve the soteriological problem as to why God becomes flesh, as a dogma of some Christian belief systems, is finally exposed in adversarial exposition as inadequately supported by one of his main arguments, designated here as Collingwood's Dilemma. The dilemma is that sin is either forgiven or unforgiven by God. If God forgives sin, then God's justice is lax, whereas if God does not forgive sin, then, also contrary to divine nature, God lacks perfect loving compassion. The dilemma is supposed to drive philosophy toward a concept of atonement in which the sacrifice of Christ is required in order to absolve God of the lax judgment objection. God forgives sin only when the price of sin is paid, in this case, by the suffering and crucifixion of God's avatar. The dilemma can be resolved in another way than Collingwood considers, undermining his motivation for synthesizing objective and subjective facets of the concept of atonement for the sake of avoiding inconsistency. Collingwood is philosophically important because he asks all the right questions about religious atonement, and points toward reasonable answers, even if he does not always deliver original philosophically satisfactory solutions.
\end{abstract}

D. Jacquette $(\varangle)$

Institut für Philosophie, Abteilung Logik und theoretische Philosophie, University of Bern, Unitobler, Länggassstrasse 49a, 3000 Bern 9, Switzerland

e-mail: dale.jacquette@philo.unibe.ch 
Keywords Atonement - Collingwood, R.G. · Divine-mortal relations · Forgiveness · Justice $\cdot$ Repentance $\cdot$ Sin $\cdot$ Soteriological problem

\section{Collingwood's philosophy of religion}

The logical and metaphysical dimensions of religious atonement, in a dialectic of repentance and divine forgiveness, is implicit in much of theological and theistic philosophical thought and discourse. The concept of atonement requires an understanding of nothing less than the relation between God and each individual soul. It is by act of will that a sinner commits a sin, by another act of will that the sinner may repent and seek forgiveness, and by still another act of divine will that the sinner is forgiven. In his quirky 1916 book, Religion and Philosophy, R.G. Collingwood describes a dialectical process of religious atonement, involving a reciprocal participation of human sinner and divine judge, that occurs over several specific distinct moments in a kind of dance:

Here we seem to have a relation involving two separate activities, the divine and the human. On the one hand there is the initiation of the repentance, the act of punishment or forgiveness on the part of God; and on the other, the response to God's act, the repentance of man in virtue of the original self-expression of God [i.e., the Incarnation]. ${ }^{1}$

Collingwood's thoughts on religious atonement and the relation between God and sinners offer a unique perspective on a central theological problem. The insightful philosophical content, given, or perhaps despite, the limitations of Collingwood's explicit Christian religious orientation and faith, can be appreciated as raising important questions for philosophy of religion, even if Collingwood is not always considered as yielding satisfactory answers. As an effort to understand the metaphysical presuppositions of theological discourse, Collingwood's rigorous if occasionally flawed philosophical analysis of the concept of religious atonement as a dialectical process between willful acts of repentant sinners and a forgiving God, a rarity within the relevant philosophical literature on religious concepts, deserves serious attention, regardless of the reader's own religious or philosophical inclinations.

What follows is an alternately explanatory and critical exposition, in which Collingwood's concept of religious atonement is explained and tested, weighed against objections, and finally evaluated for its philosophical strengths and weaknesses, moving from principal to peripheral topics, as Collingwood in his 1916 treatise explores the concept of religious atonement personified in the incarnation of Christ. The picture of Collingwood's philosophy of religion that emerges at the end of this critical exposition emphasizes ideological characteristics of Collingwood's religious philosophical thinking, in the course of explaining both its explanatory resources and deficiencies.

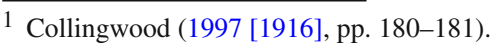




\section{Dual-aspect metaphysics of atonement}

Philosophy of religion sometimes assumes the theoretical burden of explaining the kind of relational and especially epistemic and metaphysical properties that might be ascribed to those seeking atonement with God. Collingwood describes the elements of the essential religious moments in a process of atonement as a series of ontically reductive Christianized identities, whereby Collingwood maintains that Christ $=$ the Incarnation $=$ the Atonement.

The capitalization and definite article Collingwood introduces are intended to provide alternative proper names for Christ, once Collingwood's theory of Christian repentance and foregiveness as moments in the dialectical process of divine atonement is advanced. To refer to atonement with no capitalization is just to invoke the concept of repenting and being forgiven, whereas the Atonement for Collingwood is made identical to the person of Christ, further identified as God's Incarnation. The conceptual interconnections of sincere repentance and divine forgiveness, in bringing an individual human being and God together in harmonious, nondiscordant will, is philosophically intriguing in its own right, even for those who do not share Collingwood's Christian faith, and his discussion goes far to highlight some of the most interesting philosophical aspects of what believers may mean by repentent sinners seeking atonement with God.

Collingwood's typographic convention is consistently followed here, speaking of the general concepts of 'atonement' and 'incarnation' in lower-case, and of 'the Incarnation' and 'the Atonement', having grown capital letters, as alternative proper names for what Collingwood takes to be the embodiment of God the Father in the historical personage of Jesus Christ of Nazareth. We can then intelligibly apply Collingwood's distinction when inquiring into the atonement achieved by the Atonement, and of the Atonement's reconciling God and repentent sinners with no breach of divine justice, by means of God's incarnation in the Incarnation. ${ }^{2}$

The explanation reflects fundamental religious attitudes that can overlap with philosophical conclusions concerning the nature of soul in the living experience of each individual consciousness. The sinner's efforts to return to God can reinforce the penitent's grasp of being related as a single mortal creature to the will and moral judgment of a divine creator, the Creator. Collingwood proposes a dual-aspect metaphysics of atonement in its relation to repentance and forgiveness. Part III, Chapter II of Collingwood's study, marks the Christian-philosophical dramatic denouement, in which Collingwood, having prepared the necessary background, devotes full attention to the problem of understanding divine atonement. More unexpectedly, perhaps, Collingwood in this context and from this perspective also addresses the incarnation or soteriological problem, as to why God is supposed to have been born as human flesh. Collingwood thereby attempts to draw philosophically interesting connections between divine atonement and incarnation.

The idea that Atonement and Incarnation should be explained as dual aspects of the same religiously significant phenomenon, the supposed embodiment of God in the

\footnotetext{
2 See also the essays collected in Collingwood (1968). Hogan (1989). Johnson (1998).
} 
humanity of Christ, requires an adroit application of Collingwood's conceptual analytic and synthetic philosophical skills. The argument reflects Collingwood's background knowledge and capabilities as a professional historian and philosopher of history and its methods, and depends especially on his familiarity with the history of Christianity and Christian philosophy. So focused and finally fervent is Collingwood's own Christian sentiments in the book, that as the later chapters unfold, there is virtually nothing said, even at the sociological level, concerning other religions. Nor, despite Collingwood's quite general reference for these reflections in the book's title, is any significant foray into comparative religions made from the standpoint of Collingwood's dual aspect life of Christ's nature as fusion of the Incarnation and Atonement.

Thus, Collingwood characteristically explains: 'By the central doctrine of Christianity I mean that taking-up of humanity into God which is called the Incarnation or the Atonement, according as the emphasis is laid on God's self-expression through humanity or man's redemption through the spirit of God. ${ }^{3}$ Collingwood leads everywhere throughout his philosophical inquiry with the concept of Atonement, making it primary in his explanations. To this starting place, the concept of Incarnation is eventually brought into the picture with its own conceptual baggage as the most physically intimate, and hence most religiously significant, historical moment of contact between human beings and God. Atonement seems to explain the need for incarnation, as much as incarnation, properly understood, explains the nature of divine atonement. The asymmetry between these dual aspects for Collingwood remains that there can be no atonement without God's incarnation as Christ, although logically speaking it is the need for atonement rather than the Atonement itself that motivates, philosophically justifies, and explains the Incarnation. ${ }^{4}$

The challenge in understanding this central part of Collingwood's Christian philosophy of religion is that of filling in some of the blanks tantalizingly left open in his characterization of the metaphysical status of divine atonement, in which the figure of Jesus Christ is supposed to be simultaneously in alternate lights both Incarnation and Atonement. The ontology on which Collingwood's philosophy of religion seems to be governed at its most basic level is one that emphasizes atonement as a vital process involving several stages, a series of events taking place in time affecting the properties of objects as they unfold in a specific dialectic.

Atonement, sincere repentance, and forgiveness, are the three moments or stages in a complex dialectic, arrived at through an act of the sinner's will in relation to

\footnotetext{
3 Collingwood (1997 [1916], p. 147).

4 Collingwood explains his understanding of religious doctrine in the form of propositionally expressed belief as essential to religion as he understand the concept, at least for his purposes in the book. See ibid., p. 12: 'Now the Doctrine of God is of course theology; it is in fact the translation of that word. Accordingly, a creed is a theology, and there is no distinction whatever between Theology and Religion, so far as the intellectual aspect of religion is concerned. My theology is the beliefs I hold about God, that is to say, my creed, the intellectual element of my religion.' Ibid.: 'Without examining further theories of the same kind, therefore, we may venture to assert that religion cannot exist without a definite belief as to the nature of God. This contention would probably be borne out by any careful investigation of actual religions; every religion claims to present as true and intellectually sound a doctrine which may be described as a theory of God.'
} 
God's merciful judgment. The two voices in the dialectic are the sincerely repentant mortal sinner seeking atonement, and a perfectly benevolent forgiving God. Spiritual atonement, for Collingwood, with his explicit Christian leanings, as remarked, is only to be found in the Atonement, which is to say in different words, the Incarnation, God in human form, Jesus of Nazareth, as mortal avatar of a triune Godhead. For Collingwood, the drama that unfolds after Christ enters the Temple at Jersusalem as a moment in his compassionate but revolutionary authority-defying ministry, subsequently paying the penalty by crucifixion at the hands of presiding Roman officials, fully explains the facts of Christian theological-philosophical soteriology. It accounts rationally for why it is that God had to become human in the sense of historically inhabiting a man's flesh.

All these developments are methodologically interesting as a largely neglected chapter of recent philosophy of religion. They constitute a remarkable chapter in the considered reflections of a leading, widely-read, and professionally respected, if somewhat out-of-mainstream, philosophical thinker of the time. The implications of Collingwood's concept of atonement are so fundamental, that philosophy of religion cannot avoid the question as to whether he correctly understands the dialectics of God's forgiveness for repentant sinful acts of will.

\section{Sincere repentance + forgiveness $=$ atonement}

The concept of religious atonement is literally that of becoming at-one. Atonement is attained after committing an offense against another who is at first alienated from the offender, and then brought back together in harmony. If I sin against God, whatever this means in specific application, then I have estranged my will from God's. I have done something that God wills me not to do.

My subsequent atonement with God, if achievable, must bring my will back into agreement with God's. Needless to say, this does not mean that I come to will all that God wills, or with anything remotely resembling the efficacy of God's will. Only that I begin again to will nothing that is contrary to God's will, insofar as I hope to understand whatever it is that God wills. It is religious teaching in some traditions to consider atonement as a dual-aspect phenomenon that can alternatively be described from complementary perspectives as an interrelation, almost a logical and conceptual blending, of reciprocal psychological acts of penitence and forgiveness. The offender must be truly penitent, and the offended must truly forgive, in order for the distinct moments in an act of atonement to take place.

Sincere repentance as manifested by reformed behavior in better conformity with an understanding of God's will logically implies forgiveness from a morally perfect being. Therewith, God's will and the will of the repentant sinner in this limited respect are made at-one. The sinner then attains a first or restored atonement with what is perceived to be God's will. The subordination of individual to divine will that is assumed in many religions is negotiated in this way, and is psychologically a factor for many persons in the pursuit of moral harmony and peace of mind. Ardent Christian believers sometimes speak of needing to get right with God, where the main part of what this means seems to be explicable as divine atonement. Whereas my neighbor 
may stubbornly choose not to forgive me for letting my goat loose in his yard, even after I apologise, make recompense, and make sure that it can never happen again, pasture my goat elsewhere, have the animal for dinner, or the like, my neighbor and myself, imperfect beings that we are, may remain as a matter of historical circumstances, when all the facts are known to both, indefinitely estranged. God's forgiveness as the response of a perfectly benevolent, morally perfect merciful judge, in contrast, cannot possibly be withheld, however unforced the attitude may also occur as a judgment of God's free will and divinely compassionate nature.

\section{Atonement mortal and divine in Collingwood}

Collingwood's philosophical framework makes it possible to interpret some key historical facts surrounding Christ's ministry in its conceptual cultural context. Yom Kippur, in this connection, is widely known as the Jewish Day of Atonement, in which believers ask God for forgiveness of sins. It is preceded by Erev Yom Kippur, in which those who want to ask God's forgiveness the following day must first forgive others, effectively their neighbors and peers. If a person cannot forgive others, then why expect God to forgive one's own sins or other moral or religious offenses?

From the standpoint also of Collingwood's Christian philosophy of religion, the practice of local forgiveness associated with Erev Yom Kippur can be understood to lend significance to the fact that Jesus preached the Hebrew Testament maxim to love one's neighbor as oneself, before having a right to expect forgiveness for one's own sins before God. As one reads in Leviticus 19:18, NIV: 'Do not seek revenge or bear a grudge against one of your people, but love your neighbor as yourself'. If, as Collingwood believes, proceeding on philosophical grounds coincident with the main lines of his Christian faith, that Jesus of Nazareth, later the Christ, is the living Incarnation of God as embodied sin-forgiving Atonement, then it is natural to find Christ encouraging local forgiveness of one's neighbors, friends and especially enemies alike. Christ does so often, when he preaches, specifically as a preparation for the greater atonement that his incarnation is intended to confer on faithful believers. Christ as IncarnationAtonement, on a Collingwood-inspired dual-aspect interpretation of these moments in the unfolding of Christ's ministry, breaks the costly bonds of Jewish priestly authority and offers direct contact in his own human person with God's forgiveness. It is this dual nature that Collingwood seems to believe Christ represents, in which every day in spirit is both Erev Yom Kippur and Yom Kippur.

The most obvious deeply pervasive connection between Collingwood's dual-aspect nature of Christ as divine Atonement and human Incarnation is found in Collingwood's effort to address the soteriological problem of how and why God might be thought to have become flesh. Collingwood's Christian philosophy of religion partly absorbs and partly distances itself from a more or less doctrinal composite Christian religious worldview. The soteriological problem is resolved in Collingwood's philosophy as the essential incarnation requirement for attaining atonement between human sinners and God. It is meant to accord with what conventional nonphilosophical believers have sometimes expected to be implied by God's incarnation as Jesus. God's perfect benevolence, in accepting atonement without exception from 
those who are sincerely repentant in seeking forgiveness for their sins by making their wills at one with God's, completes the picture of Christian divine atonement. Mankind through the person of Jesus is atoned, made at-one, with God, according to a still surviving Hebrew Testament concept of attaining atonement, by the intermediary of a sacrificial lamb of God, something that Collingwood argues could only occur if Jesus were identical with God. Jesus is the Incarnation of and hence the embodied Atonement of God's will with the will of God's human creation. As incarnated God, Jesus brings humanity and the divine together in his own person, while in the story of the passion, Christ's crucifixion appears politically as much a tale of angry materialistic power struggle as of gracious forgiveness and divine atonement.

Regardless of the factual historical merits of this part of the narrative, it is roughly the composite story of Christ that Collingwood in his impassioned philosophical Christianity seems unequivocally to accept. The philosophical portrait of Christ Collingwood paints in two dimensions is that of God incarnated, and as such the most powerful imaginable symbol of divine forgiveness. Collingwood considers divine atonement to come in the form of, and as really nothing other than, God's incarnation as Jesus. God's incarnation, the Incarnation, is Christ, and Christ, by virtue of being the Incarnation, is also thereby necessarily the Atonement. Incarnation implies atonement, at the highest conceptual level for Collingwood, against a background of additional metaphysical assumptions and devout commitments, about which he is mostly silent. Atonement is historically revealed in the same moment that it is implemented as the product of God's infinitely good will in the incarnation of God in the person of Christ.

It all fits tightly together, once the first steps are taken toward Collingwood's analysis. From a Christian philosophical or philosophical Christian standpoint, Collingwood's exposition presents atonement and incarnation as two sides of the same coin, when we grasp conceptually that the Atonement $=$ the Incarnation $=$ Jesus of Nazareth, the Christ. Collingwood, who implies by the title of his book that he has something to say about philosophy and religion generally, advances a philosophical concept of atonement that is not transportable to any other religions that do not recognize that Jesus of Nazareth was the avatar of God, and or, as some later Christian councils were eventually to decide, in some sense perhaps even identical with God or a part of God's godhead, rather than merely a good man and wise moral teacher. Collingwood's arguments speak no word as to the concept of atonement, if any, in the religious dogma and practice of faiths other than Christianity, in which the concept of God's human incarnation may not only be excluded, but forbidden as heretical, altogether contrary to the faithful's understanding of God's nature.

\section{Inherently distorting objective atonement theologies}

Collingwood develops his dual-aspect metaphysics of atonement by explaining that repentance and forgiveness are not distinct dialectically unrelated occurrences, but 
'inseparable aspects of one and the same process', logically interimplicative when combined with the background propositions Collingwood assumes. ${ }^{5}$

Atonement is a dialectical process involving two persons, the human sinner and divine font of forgiveness. If we try to detach these moments of the process from one another, then we are certain to arrive at a distorted understanding of the general concept of atonement. The two resulting theories, emphasizing the human side of the process exclusively while making the divine secondary, or vice versa, Collingwood refers to respectively as the subjective and objective 'theories' of atonement. The two artificially abstracted theories, detached from the common developing root and stem of atonement, as an interbraiding of moments between sincere human penitence and divine forgiveness, he regards as doomed to fail in efforts to understand the nature of atonement. To suggest an analogy that Collingwood does not consider, such explanatory folly would be the equivalent of trying to understand the nature of money by concentrating only on the material paper, metal, and plastic-electronic, in which monetary values are embodied, without reference to the values themselves, or, contrariwise, only to the exchange values of money considered in the abstract, without regard for its many different concrete forms of material embodiment. Collingwood in his own words similarly explains:

These are two inseparable aspects of one and the same process; the tendency to lay exclusive emphasis on one or the other leads to two main types of theory, each equally unsatisfactory because each, while really one-sided, claims to be an account of the whole truth. These views I call the objective and subjective theories, respectively. ${ }^{6}$

On the objective theory of Atonement, a sinner's seeking atonement in the form of forgiveness is also God's doing, and the whole business is an act of God in several movements. We may nevertheless be disappointed in asking whether the performance of which Collingwood speaks also includes the sequence-initiating sin or falling out of a presumed initial state of grace with God's will on the part of the individual human sinner. Completing the whole picture by beginning with an act of sin in transgressing God's will, as the originating occasion for atonement-seeking, would seem to be demanded by logical consistency, although Collingwood does not acknowledge the problem or recommend any provisions for supplying the omission. He merely distinguishes:

(a) The objective theory of atonement points out that whatever change takes place in the human will is due to the free gift of the Spirit of God. Men can do nothing good except by virtue of God's grace, and therefore, if the evil will of man is converted into a good will, the whole process is an act of God. The Atonement, the redemption of man, is a fact entirely on the side of God, not at

\footnotetext{
5 Ibid., p. 182: 'In examining actual theories of the Atonement [event of the Incarnation], however, we must bear in mind that a verbal statement which appears to be one-sided does not necessarily either neglect or exclude the other side. The objective view is perfectly true so far as it goes; and the criticism often directed against it, on the ground that redemption is a matter of the individual will alone and must arise entirely from within, is due to a fallacious theory of personality.'

6 Collingwood (1997 [1916], p. 181).
} 
all on the side of man; for without God's help and inspiration there would be nothing good in man at all. ${ }^{7}$

If consistency is expected, Collingwood must affirm that atonement, in the existence of the Atonement, is all God's doing. It is all the unfurling, then, as he maintains, of a divine 'process'. God bends human will out of agreement with God's will, and then brings it back into being at one with God's. If that is Collingwood's concept, it does not obviously make sense. How can God will to have a human being's will not agree with God's will? If God wills such a thing, then whatever the human being wills to do must be precisely part of what God wills, rather than something that could possibly be out of step with God's will. If God wills this first initial state moment of the total Atonement process, then what a human being wills thereafter cannot logically be at odds with any part of God's will.

Moreover, how is it supposed to be thinkable on Collingwood's assumptions for God's will ever to be opposed? If God truly wills something, how can God's divine causally efficacious omnipotent will conceivably be countermanded by any act of human will? How can anything occur anywhere in the universe that is not necessarily the expression of God's will? God wills that no human being murder another, we are encouraged to believe. In actually committing a murder, we nevertheless generally suppose that a killer blatantly defies God's will, and thereby stands in need of atonement.

The options here are few, if we are not simply to throw up our hands philosophically and announce that whatever anyone chooses to believe is beyond the reach of justification, and in some sense an irreducible matter of faith. We are certainly limited in one otherwise promising direction, if we try to say that God has no will whatsoever, pro or con, concerning what any human thinking acting psychological subject wills. Then there will be no basis for atonement in the first place, as Collingwood understands the remaining two-part process of sincere repentance and forgiveness. There can be no motivation for restoring the wayward will of a human sinner to a state of being at one with God's will, with which it cannot logically conflict. Repentance for doing what, in that event? Forgiveness for having done what? If God entertains no particular will concerning what human beings might do or will to do, as Deists profess, then there can be no atonement-originating moment of discord between finite human will and whatever God wills to pave the way for reconcilation, in what Collingwood describes as the remaining essential dialectical moments of repentance and forgiveness in the process of atonement.

The philosophical justification for the 'objective' theory of atonement remains powerful, in light of the consideration that the contribution of the human moment of repentance to the process of atonement is incapable of accomplishing anything, of taking even the first steps toward becoming at one with God's will, without God's supportive activity and initiative:

\footnotetext{
${ }^{7}$ Ibid.
} 
The divine grade of Atonement consists in the imparting not of a new ideal but of a new power and energy to live up to the ideal. Man, in a word, cannot redeem himself; his redemption comes from God and is God's alone. ${ }^{8}$

The 'objective' God-originating and God-sustaining account of atonement is nevertheless conceptually limited by the fact that redemption of the sinner is a matter first of the sinner's will, and of a change in the sinner's will upon sincerely seeking redemption in an act of divine forgiveness. If God is objectively totally responsible for all three moments in the complete dramatic process of atonement, then there seems to be no place left in the account for the sinner to willfully choose a return to agreement with God's will. Nor similarly is there then an opportunity for the penitent to arrive at sincere independently motivated repentance in desiring to be at-one with God:

Now this "objective" view is exposed to the danger of forgetting that redemption must be the redemption of a will, the change of a will; and that in the last resort a will can only be changed by itself. If this is forgotten, the objective theory lapses into an abstract legalism according to which grace becomes a fictitious and conventional restoration to favor without any corresponding renovation of character. These two things must never be allowed to fall apart in such a way that the Atonement consists in the one to the exclusion of the other; for unless the grace of God awakes a response in the will of man there is no true atonement. But this response is just the fact which this type of theory tends either to overlook or at least to describe with insufficient accuracy. ${ }^{9}$

The will of a murderer we may suppose is free in a sufficiently clear and robust sense to support the agent's moral responsibility before God. Philosophically, we must still wonder how such discordance between human and divine will could have imaginably occurred. If it is truly God's will that murder not occur, how then is it even logically possible for humanly willful murders to occur in blatant defiance of God's will? We cannot assume, on the basis of any distinction Collingwood mentions, that whatever God wills to be the case can possibily be contradicted or contravened by the actual state of affairs in the world that God is supposed to have created in the first place through an all-powerful perfect act of divine will and moral decree.

The problem is easy to express, but surprisingly more difficult and elusive satisfactorily to answer. If God wills there to be no murders, how can it be the case that there are? If God does not will it, then how can an estrangement of human and divine will arise when someone supposedly defies God's will by actually committing a murder? Collingwood investigates the topic of Free Will, in his tall letter orthography again, which he interestingly pairs conceptually in the book's final chapter with the concept of Miracle. We might wonder whether such a turn too facilely covers too much ground. Further pursuit would take the present inquiry in a fascinating but side-tracked direction. The immediate point is only that if Collingwood's 'objective' theory of the Atonement is accepted, then, in lieu of special pleading, it would also need to incorporate that part of the atonement process in which the sinful mortal will's

\footnotetext{
8 Ibid.

${ }^{9}$ Ibid., pp. 181-182.
} 
transgression takes place. Then God, paradoxically, must will a departure from the will of God. The bounds of rationality are thereby strained in even the most philosophical exposition of religious doctrine.

If powerful apologetics can be enlisted to help make sense of this apparent contradiction, the resulting 'objective' account, at its best, intuitive plausibility issues aside, still implies that God wills that the sinner exercise free will in transgressing against other intended purposes of God's will. The 'objective' account of the atonement process that Collingwood criticizes makes God's will causally and morally responsible for the sins and related offenses supposedly against God's will that human sinners sometimes commit. The implication is logically trivially supported by the inconsistency that God wills God's will not to be fully actualized, from which literally any proposition is validly deduced, ex falso quodlibet.

What might be called Collingwood's Dilemma underlies most of his accompanying discussion of 'just punishment'. As further exploration into the interior of these densely interrelated concepts, Collingwood argues first that we cannot have an adequate concept of repentance or forgiveness, essential moments of the atonement process occurring through God's human incarnation, without an adequate concept of just punishment. It is God's just punishment for the sinner's infractions against God's will for which God offers divine forgiveness to the sincerely repentant sinner seeking atonement. God's divinely just punishment is compared by Collingwood to what we are inclined to consider just punishment in human affairs. The interest here is not to try to learn about the divine from secular matters, nor to recognize signs of the divine in secular circumstances. Nor is it Collingwood's purpose to arrive at a moral or epistemic justification of the secular by appeal to the divine and its agreement therewith, or vice versa. The objective theory of atonement that Collingwood hopes to develop is nevertheless subject in its divine-favoring one-sidedness to the dilemma that issues from the disjunction that sin is either forgiven or unforgiven by God. If sin is forgiven, then Collingwood is concerned that God's supposedly perfect justice must have gone lax, no longer meeting the conceptual requirements of fully righteous justice. If sin is unforgiven, then the failure of atonement is incompatible with sincere repentance and the amending of ways on the part of a perfectly good, perfectly benevolent loving fatherly or motherly divine compassionate godly Spirit. To be forgiven without further ado and still receive just punishment, in order to preserve both concepts of God's perfect benevolence and God's uncompromising divine justice, is not countenanced as a logically possible option for the God of Collingwood's Christianity.

The objective theory of Atonement as Collingwood describes it, for all these reasons, seems logically incoherent. The fundamental concept is extended more consistently to comprehend not only the sinner's act of repentance. It must also in fairness incorporate the process-originating sin, the act of transgressing against God's will in the first place. It is represented in the Garden of Eden story as the tree of forbidden fruit. Collingwood's Christian philosophical ideology is beset by the dilemma of just punishment for sin, of God's either forgiving or not forgiving sin for the sake of foregoing justly deserved punishment. Completeness at the expense of logical consistency is by no means an unprecedented trade-off in theoretical philosophy. It is interesting, nonetheless, to see the dilemma play itself out in Collingwood's unlikely application, 
involving an informal discursive analysis of the concept of religious atonement in relation to God's incarnation in the person of Christ as the Incarnation = the Atonement.

\section{Equally fallacious subjective account of atonement}

What are we left with, permitting all such difficulties to pass for the moment, and purely for the sake of argument, if we abandon the objective concept of atonement? The unphilosophical view, one imagines Collingwood rejoining, is that atonement and incarnation are two different things, related only insofar as the Incarnation provides part of the bridge for the sinner's atonement with the will of God.

God becomes flesh in Christ, as Collingwood's Christian philosophy implies, as the perfect fulfillment of God's benevolent will to offer universal atonement to all sincerely repentant sinners. Collingwood, in this vein, does some fancy side-stepping in order to extend the Christian Gospel also to those who have never heard the redeeming message. Why are the unwashed not simply damned to eternal hell? The Incarnation of God in Christ's flesh is the Atonement itself, Collingwood insists, not merely the conduit by which a sinner may seek to attain atonement, on the philosophically most interesting part of Collingwood's synthesis that survives criticism. It is the expression of God's will for the world, that all other human (and angelic?) will be harmonized with God's own divine intentionality. That, apparently, is something that cannot itself simply be willed, although it is God's will that it should occur, and God's will is insuperable, omnipotently, cosmically causally efficacious.

On balance, there does not seem to be much hope for what Collingwood calls the objective theory of the Atonement as a facet of the same process of discord and redemption, bringing human will to stand at one with the relevant part of God's will made immortal flesh in the Incarnation. If the objective theory is a non-starter, what more if anything can be said on behalf of Collingwood's Atonement-Incarnation duality from the alternative, presumably exclusively subjective, side of the opposition that Collingwood invokes rhetorically in order to transcend?

What Collingwood distinguishes as the 'subjective' theory of atonement honors the insight that repentance from the human quarter in the several-stage process of divine atonement must be the result and reflection of a free act of will on the part of the sinner who in a deliberate act of iniquity has fallen out of oneness with God's will. The mirrorimage subjective account of divine atonement, in contradistinction to the objective, provides the other equally ineffectual half of a complete picture of atonement between human sinners and God. Such a theory suffers explanatory disadvantages, according to Collingwood, when it is detached from its objective component, just as the objective does in isolation from the subjective. The subjective theory is inadequate considered only in itself apart from the subjective, where neither aspect of the dual-sided nature of the process in and of itself offers a satisfactory understanding of the logic and metaphysics of divine atonement. Collingwood argues:

(b) The "subjective" theory insists on the attitude of man to God, and lays down that since redemption involves an attitude or state of the subject's will it cannot without violence to his freedom be brought about by the act of another person, 
even if that other person be God. Grace as something merely proceeding from God is not only a hypothesis, but a useless hypothesis; the fact to be explained is the change, repentance, reformation of the individual, and this fact cannot be experienced by reference to another's actions. Nobody can change my mind for me except myself. The question in short is not, What change has occurred in God?-since God is and always was long-suffering and merciful. It is rather, What difference has the life of Christ made in me? How has his example fired me to imitate him, his life challenged me to new effort, his love called forth love in me ${ }^{10}$

The allure of the subjective theory of atonement is outweighed by its most significant disadvantage. Collingwood describes the defect in the subjective theory as duplicating the chief failure of the objective theory. Both objective and subjective theories describe a moment in the process of divine atonement whereby either the repentant human sinner sincerely seeking forgiveness or God as divine judge is entirely inactive as a willful partner, the sinner falling out of accord with God's will, and then entering back into a redemptive state of being at-one. Collingwood rejects the subjective approach to understanding divine atonement, even as a general philosophical concept, and more certainly as Atonement $=$ Incarnation $=$ Christ, in the sense that he accepts and wants to promote:

The tendency of subjectivism on the other hand is to assume that the righteousness of man is independent of his relation to God; that man's will is sanctified by his own effort whether he is justified in the eyes of God or not. Here again the fault lies in the absolute separation of man from God. God is not realised as the one and only source of goodness; it is not understood that to will the right is to unify one's will with God's. ${ }^{11}$

Collingwood's philosophical point is that the process of atonement cannot be properly understood except as an interaction of conjointly participating moments of divine and human will, where both play an essentially active role that no adequate understanding can afford to overlook or downplay. If we feature either the human or the divine moment of the process at the expense of the other, then we are certain to misunderstand the nature of atonement. The only proper, complete and undistorted view for Collingwood is the holistic consideration of the complementary roles played by sincere human repentance in dialectical interaction with perfect divine forgiveness, in the course of attaining an atonement of mortal will with God's divine infinite will. ${ }^{12}$

\footnotetext{
10 Ibid., p. 182.

11 Ibid., pp. 185-186.

12 As useful background companion to Collingwood's metaphysics more generally, independently of its applications in his philosophy of religion, refer to Collingwood 1998 [1940]. Among the secondary literature see also Rubinoff 1972, and the essays collected in Krausz (1972).
} 


\section{Collingwood's religious conceptual synthesis of objective and subjective models of atonement}

Collingwood's own dialectical narrative arc now swings from thesis $(a)$, an objective divine model of atonement, to antithesis $(b)$, the subjective cousin of $(a)$, to which it is alike in all the wrong ways. Building on the fact of their failure, Collingwood then proceeds to a more defensible synthesis $(c)$. He believes the truth to be found not in either extreme, but in a philosophical meeting of these ideological polestars in a more encompassing synthesis in the concept of the Atonement that does not merely combine objective with subjective elements:

(c) It must be obvious by now that of the two theories sketched above, each is an abstraction; each emphasises one side of a reality in which both sides are present and in which, as a matter of fact, both sides are one. The two sides must be unified; but this cannot be effected by a compromise. A compromise is a middle path between two extremes, and includes neither. The combination at which we aim will assert both theories to the full while avoiding the errors which alone keep them apart. As often happens in such cases, the two opposing theories are based on the same error, and a little further analysis will show wherein this error consists. $^{13}$

Collingwood rejects the inherent myopia of both objective and subjective approaches in trying to understand the enigma of atonement. He tars them both with the same brush, attributing the exclusionary inner or external dichotomy, where true explanation can only be sought by recognizing the complementarity of divine and human will in bringing human will into agreement with God's. Collingwood elaborates upon his objection to $(a)$ and $(b)$ in these terms:

This is the fallacy common to the two views. Each alike holds that a given action may be done either by God [ $(a)$ objective] or by man [ $(b)$ subjective], in either case the other being inactive. This separation of the will of God from that of man is fatal to any theory of Atonement, where the fact to be explained is that man is redeemed not merely by his own act but also and essentially by God's. ${ }^{14}$

It is worth remarking that it is in these salient passages, beginning with his discussion of objective theories of atonement, and critically investigating what would appear to be efforts to arrive at a correct philosophical understanding of the general concept of atonement as a process, that Collingwood suddenly has the word 'atonement' grow a

\footnotetext{
13 Collingwood (1997 [1916], p. 184). A more recently published discussion by Kasuga (2011) argues that a balanced interpretation implies that Collingwood seeks in his philosophy of religion to overcome a number of traditional philosophical dualisms of 'realism' and 'idealism'. I propose in contrast that Collingwood regards the concept of religious atonement in particular as capable of being understood only by correctly applying an extant dualism involving precisely the realism-idealism distinction. I do not see Collingwood as departing from these two polar extremes, and I read him instead as preferring a synthetic but not merely syncretic metaphysics, in which each of these opposite concepts lends an essential complementary dimension to a more complete grasp of the dialectical dynamics of religious atonement.
}

14 Ibid., p. 185. 
capital letter, appearing thereafter in the text, as the proper names 'Atonement' and 'the Atonement'. This, for Collingwood, we know from previous passages, is ultimately just one side of the dual-aspect person of Jesus, construed as God made flesh and blood in the Incarnation.

Such vital religious phenomena are mysteries for others, in Collingwood's judgment, only insofar as they do not light upon the correct metaphysics. He seems to think he has accomplished precisely this in his dual-aspect theory of the AtonementIncarnation. It might be replied, in stricter observance of Collingwood's own distinctions, assuming that he has been well-served by his typesetter, that the objective and subjective theories he criticizes were never intended as theories of Atonement, in which God's and human will are joined together as dual aspects of Jesus Christ, for the sake of understanding the general concept of atonement, without the capital 'A'. If not a frustrating series of inconsistent typos, if Collingwood understands the capitalization of Atonement and Incarnation as we have interpreted it, logically, as co-referential designations of Jesus, then we cannot have a satisfactory dual-aspect account of Atonement, sporting a capital 'A', if we try to deny one aspect to the exclusive emphasis of the other.

The model that Collingwood considers philosophically correct is rather one that explains Atonement, here sporting the proper name capitalization, as an event in which both human and divine will act in concert in a single fused moment, in which both parts are equally active in different ways and playing very different complementary roles. Collingwood adds:

A satisfactory theory of the Atonement seems to demand that the infusion of grace from God does not forcibly and artificially bring about actually is a change of mind in man. It is an event which only co-operation of the various wills involved can effect at all. The error of the objective theory (or rather the error into which that way of stating the truth is most liable to fall) is to regard God as wholly active, man as wholly passive; and to forget that God's purpose of redemption is powerless apart from man's will to be redeemed. ${ }^{15}$

Collingwood's dual-aspect account of Atonement-Incarnation in the drama of Christ is adapted to resolve what are otherwise independently impenetrable paradoxes, when seen only from a single perspective emphasizing a single aspect to the neglect of its corresponding aspect, to be appreciated from a similarly complementary perspective. He continues:

The two things - righteousness and reconciliation with God-are really one and the same, and to represent one as means to the other or vice versa, or to insist on one and neglect the other, implies forgetting their identity and making an arbitrary and false separation of the two. ${ }^{16}$

The synthesis of objective and subjective aspects of Atonement-Incarnation in Collingwood's Christian philosophy of religion is no mere bolting together of God's

\footnotetext{
15 Ibid.

16 Ibid., p. 186.
} 
external objective relation to human will, as understood from the human perspective, with the internal subjective change of heart by sinners seeking repentance and atonement, and thereby desiring a reconciliation with God's will. To project such a crude combination is still to separate conceptually the main ingredients in the symbiosis of human and divine wills that is supposed to occur in human-divine Atonement. As Collingwood ingenuously argues:

Neither is it enough merely to combine the two sides which the foregoing theories have separated. That would be to make the Atonement a combination of two different acts_-God's forgiveness and man's repentance-of which each is peculliar to its own agent; it would fail to account for the essential unity of the whole process, and taking the two sides as co-ordinate and equally vital, would substitute an unintelligible dualism for what is really one fact. ${ }^{17}$

To summarize, Collingwood insists that, 'The failure of the theories hitherto examined has been in every case due to this distinction within the Atonement of two sides, God's and man's.' ${ }^{18}$ How this condition is achieved in Collingwood's treatise is not so much inferred from evident assumptions as articulated and explained philosophically. Collingwood characterizes Atonement without attempt at further justification, saying only in gender-biased terms, that, on the proposed dual-aspect model, "we shall be able' to describe Atonement as 'the re-indwelling of the divine spirit in a man, who has previously been alienated from it.' 19

\section{Necessity of Christ's passion in Collingwood's religious philosophy}

Collingwood's enthusiastic identifications of further religious concepts with Christ's inextricably intertwined dual nature as Atonement and Incarnation is simultaneously metaphysically interesting and conceptually frustrating. It appears that once we have atonement incarnate, then any and everything that is in any way difficult to understand in the implied Christian ontology, or to reconcile with prephilosophical concepts of God, is collapsed into the concept of Atonement-Incarnation in the life and death of Christ.

The concept of Christ's suffering, the passion, which we might win Collingwood's approval by designating the Passion, predicated on the Incarnation, is plausibly analyzed in the general framework of Collingwood's idealist philosophy of religion. Because Christ suffers as a human being, because Christ is the concrete symbolic unification of human-divine Atonement in the putative historical fact of God's Incarnation, Christ's passion, physical punishment and execution by Roman legionnaires, is joined together conceptually as one again by Collingwood reductively in the person of a suffering sinless Christ. Collingwood explains:

\footnotetext{
17 Ibid.

18 Ibid.

19 Ibid., p. 187.
} 
But this universal fact of human life [that the suffering of others is 'the influence by which we come to our own repentance'] is, like all others, summed up and expressed most completely in the divine manhood of the Christ. He alone is always and perfectly penitent; for a sinful man cannot, while sinful, repent of his own sins or any others; permanent penitence is only possible for a permanently sinless mind. And this repentance of Christ is not only subjectively complete, that is, unbroken by sins of his own, but objectively perfect also; it is incapable of supplement or addition, sufficient to atone for the sins of the whole world, to convert all sinners by the spectacle of God's suffering. ${ }^{20}$

Collingwood does not pause to consider what a sin-free subject could possibly have to be penitent about. If pressed, he might resort to Christ's not being identical to Suffering in the same way or in the same sense that Collingwood would have Christ identified with the Atonement-Incarnation. To make exception, Collingwood would need to speak again of the Suffering as in some sense encapsulating the entire run of Christ's life from miraculous birth to crucifixion.

It is an established problem of Christian apologetics that Collingwood inherits rather than invents, one that is perhaps best addressed in Collingwood's structure of conceptual linkages in his philosophical reconstruction of Christianity, as Christ's vicarious penitence. Christ's passion, as frequently remarked, is an assumed rather than acquired guilt and blame. Christ takes on the role prescribed by lesser creatures in a variation of the Hebrew Testament ceremony for symbolically removing sins from human wrongdoers and transferring them to a living scapegoat, 'punished', if that is the right way to think about it, by having its throat slit for a barbecue. Christ, as Collingwood interprets this central component of Christian and other religious dogma, fulfills a representational part of the divine ransom. The Atonement-Incarnation physically embodies both functions as victim and sacrificial lamb of God, on which the sins of a repentant humankind have been vicariously disposed, and for the sake of which the Atonement-Incarnation is deputized as a combined necessity of both God's divine justice and infinite compassion.

Collingwood's discussion in this chapter, having accomplished its purpose in explaining the limitations of exclusively objective and exclusively subjective understandings of divine atonement that might naturally be considered the culmination and main message of the book, resolving their conflicting distortions in a holistic synthesis of the cooperation of mortal will and God's will, culminates in these thoughts of Collingwood's on the historical necessity of Christ's passion:

Thus the supreme example of sinless suffering is...not merely an example set up for our imitation; not merely a guarantee of the possibilities of human life. It is an unfailing source and fountain of spiritual energy; it gives to those who would imitate it the strength to work miracles, to cast aside their old selves and to enter upon a new life prepared from the beginning of the world; for out of it power goes forth to draw all men to itself. ${ }^{21}$

\footnotetext{
${ }^{20}$ Ibid., p. 192.

21 Ibid., pp. 192-193. See also Johnson (1967), especially chapter V, pp. 45-51.
} 
Collingwood, depending on one's point of view, advances or regresses in these moments of Christian enthusiasm from philosophy to sermonette. A philosophical investigation of the same cluster of concepts could undoubtedly proceed in contrast by asking more open-mindedly, first, whether and if so. in what sense Christ's passion might be considered a source of spiritual energy. It might be inquired what meaning Collingwood's references to spiritual energy could reasonably have, whether and in what sense there are miracles, and what if any relation might obtain between Christ's moral example and the possibilities of spiritual self-renewal that might be available through association with Christ's dual nature as Atonement and Incarnation, as events were fated to transpire, resulting in his suffering the Passion.

If there is to be rapprochement between God's divine infinite will and the finite moral human will of sinners seeking redemption and divine forgiveness through sincere repentance, then Collingwood believes that Christians, at some point in their greater conceptual awareness as their sect dialectically progresses, must conclude that only Christ's painfully spilled blood can satisfy the demands of God's AtonementIncarnation. If Christ is not sacrificed, in lieu at least of punishing a surrogate or vicarious subject, then Collingwood's Dilemma would have it that God's divine justice is lax. This is why Christ as Atonement-Incarnation must suffer the Passion, in order to prevent the contradiction of God's perfect justice from falling short of just punishment. Saving all grace-accepting humankind from death, and by implication from hell, demonstrates God's coeval infinite compassion. By this string of overlapping conceptual connections, Collingwood perceives a philosophical relation between Christian religious concepts of atonement, incarnation, Atonement-Incarnation, just punishment, divine infinite compassion, and Christ's physical abuse by provincial Roman overlords in ancient Judea. As a punishment for every human being's sins, the requirements of God's perfect justice and perfectly just punishment are fulfilled. God is not unjust, his will is not mocked. With Christ's crucifixion, the composite Christian narrative continues, all sinners are compassionately offered eternal life, if they only will to enter already in harmony with God's will, into the next moment of the Atonement dialectic, by sincerely repenting and being as instantly forgiven.

\section{Sin and discord with God's will as the original moment in Collingwood's dialectical concept of atonement}

The need for Atonement, for bringing human and divine will back together after discordance, seems to drive the need for God's human Incarnation in Collingwood's account. If there were no need for Atonement, what need would there have been of Incarnation, or for vicious execution of God's avatar by Roman soldiers? Like other Christians, Collingwood is obliged rationally to explain how a son of God could have been cruelly tortured to death, except as part of some larger justifying design, a reason or plan, with an internal inherent necessity. Christ $=$ Incarnation of God does not get murdered by accident, being in the wrong place at the wrong time, or inciting resentment for his words and deeds. The suggestion here links essential concepts together in a logically tight structure that contributes necessity to the events surrounding Christ's death by crucifixion, involving a process that takes place in 
definite stages, transpiring over certain moments of real time, as Collingwood rightly reminds his readers.

The resulting picture is philosophically attractive. The distinguishable components of the composite Christian narrative lock together in a satisfying way in Collingwood's philosophy. What is not adequately spoken of throughout Collingwood's account, however, as this critical examination has emphasized, is sin. Sin is nevertheless the initiating event by which the dialectical process that Collingwood is otherwise keen to explain gets started in the first place. Without sin, there is no need for atonement, and hence no need for Atonement through the Incarnation and Passion of God incarnate. Christians could only wonder then why Christ let himself be killed. Even Adam and Eve had a couple of days of being at-one with God's will, until they willed something discordant with God's will and fell out of grace. Nicely symbolized by a still popular metaphor in tasting the forbidden fruit, our first parents assuredly did something naughty, something they believed to be contrary to God's will. The Book of Genesis narrative expresses the first break of previously innocent human will from God's, as our progenitors emerged from a more primitive animal consciousness. It is presented as an incident of rebellious teenage will in almost any culture, at almost any time and place, reacting to the contrary willfulness of a perceived individual subordinate-will-denying or -inhibiting parental authority, no matter how well-meaning in intention.

The dialectic in Collingwood's account must more completely describe a process with distinct moments that cannot be set in motion unless human will takes the first step. Mortal sinners must do so, however regrettably, by pitting themselves against and thereby transgressing God's will. A human being must choose to do something that the individual believes to be contrary to God's will. Then and only then can philosophy of religion begin intelligibly to ask how and what it means for the will of sinners and the will of God to be brought together in harmony again after their breach, and made at-one. If the will of God and the will of human sinners do not first fall apart, as the opening move in the Christian drama, then there is no ground for reconciliation, and hence no initiation of the fulfilling Atonement or Atonement-Incarnation-with-Passion moments in Collingwood's dialectic of religious atonement. There would then be no essential role for Christ to play in the great Collingwoodian dialectic, in which God and human sinners enter into the most profound interrelation.

Were there no sin, there would be no Atonement, and hence no Incarnation. There would likewise be no suffering Passion. The Incarnation of God as Christ, if Collingwood's argument is correct, would never have taken place, if, speaking again counterfactually, and purely for the sake of argument, there had never been any human sin. The sinful, contrary-to-God's-will, rebelliously willful actions of mortal sinners, kickstart the dialectic of Atonement, and thereby, on Collingwood's dual-aspect theory of Atonement-Incarnation, necessitate God's Incarnation as Jesus Christ. To return in concluding to uncapitalized un-Collingwoodian orthography, there is no atonement unless there is sin. Without sin, there is no need for atonement. With no need for atonement, there is in turn no need for God's incarnation, no need for Collingwood's Atonement-Incarnation embodied in the person of Christ. Some sins must therefore be extraordinarily easy to commit, even by persons who are otherwise morally upright, righteous, virtuous and honorable. We can, by some accounts, be born into inherited sin, without having personally willfully committed any violation of God's law, and 
even before we are capable as agents of committing any willful actions, of acting with responsibility. One wonders whether it is a good or bad thing that there is not more agreement among individual and collective religious sentiment as to the exact will of God, to whatever it is that God wills, and however it is that we are supposed to be able to know. Where the epistemological problem begins, there for the moment ends the limited outlook of logical and metaphysical inquiry undertaken into Collingwood's extraordinary idealist Christian philosophy of religion.

Acknowledgments I am grateful to an anonymous journal referee for useful comments, criticisms and suggestions for improvement.

\section{References}

Collingwood, R. G. (1968). In: L. Rubinoff (Ed.), Faith \& reason: Essays in the philosophy of religion by R.G. Collingwood. Chicago: Quadrangle Books.

Collingwood, R. G. (1997 [1916]). Religion and Philosophy. Bristol: Thoemmes Press; reprint. Key Text series, Classic Studies in the History of Ideas.

Collingwood, R. G. (1998 [1940]). In: R. Martin (Ed.), An essay on metaphysics. Revised edition, with an introduction and additional material. Oxford: Oxford University Press.

Hogan, J. P. (1989). Collingwood and theological hermeneutics. Lanham: College Theology Society Studies in Religion, University Press of America.

Johnson, P. (1998). R.G. Collingwood: An introduction. Bristol: Thoemmes Press.

Johnson, W. M. (1967). The formative years of R.G. Collingwood. The Hague: Martinus Nijhoff.

Kasuga, J. (2011). A departure between two extremes: R.G. Collingwood's religion and philosophy reconsidered. Idealistic studies, 41, 31-43.

Krausz, M. (Ed.). (1972). Critical essays on the philosophy of R.G. Collingwood. Oxford: The Clarendon Press.

Rubinoff, L. (1970). Collingwood and the reform of metaphysics: A study in the philosophy of mind. Toronto: University of Toronto Press. 